\title{
COMPARISON BETWEEN TEST METHODS TO DETERMINE WOOD EMBEDMENT STRENGTH PARALLEL TO THE GRAIN ${ }^{1}$
}

\author{
Diego Henrique de Almeida ${ }^{2 *}$ and Antonio Alves Dias ${ }^{3}$
}

\footnotetext{
${ }^{1}$ Received on 20.12.2014 accepted for publication on 31.05.2016.

${ }^{2}$ Universidade de São Paulo, Escola de Engenharia de São Carlos, Laboratório de Madeiras e de Estruturas de Madeira, São Carlos, SP - Brasil. E-mail: < diegoestruturas@gmail.com>.

${ }^{3}$ Universidade de São Paulo, Escola de Engenharia de São Carlos, Departamento de Engenharia de Estruturas, São Carlos, SP - Brasil. E-mail: <dias@sc.usp.br>.

*Corresponding author.
}

\begin{abstract}
This study compares the test methods according to the ABNT NBR 7190:1997, EN 383:2007, ASTM D5764:2007, EUROCODE 5:2004, NDS:2001 standards in order to provide support to establish a new test method for determining the embedment strength of wood parallel to the grain. Parallel-to-grain tests were carried out for six wood species (Schizolobium amazonicum; Pinus elliottii; Pinus oocarpa; Hymenaea spp.; Lyptus ${ }^{\circledR}$ : hybrid Eucalyptus grandis and Eucalyptus urophylla, and Goupia glabra) using four diameters $(8 \mathrm{~mm}, 10 \mathrm{~mm}, 12 \mathrm{~mm}$ and $16 \mathrm{~mm}$ ) for the metal pin fasteners (bolts). The experimental results obtained according to the EN 383:2007 standard were closer to the specific values for the metal-dowel connections design used by ABNT NBR 7190:1997, which are considered equal compression parallel to the grain. The use of maximum embedment force or the force causing displacement of $5 \mathrm{~mm}$ between the bolt and the testpiece as criteria for determining embedment strength for EN 383:2007 appears to be more appropriate than the criteria used by the Brazilian and American Standards.
\end{abstract}

Keywords: Connections; Bolts; Timber structures.

\section{COMPARAÇÃO DE MÉTODOS DE ENSAIO PARA DETERMINAÇÃO DA RESISTENCIA DA MADEIRA AO EMBUTIMENTO NA DIREÇÃO PARALELA ÀS FIBRAS}

\begin{abstract}
RESUMO - Este trabalho compara os métodos de ensaio especificados pelas normas ABNT NBR 7190:1997, EN 383:2007, ASTM D5764:2007 e EUROCODE 5:2004, NDS:2001, com o intuito de fornecer subsídios para a revisão do método de ensaio da ABNT, para o caso da resistência da madeira ao embutimento na direção paralela às fibras. Foram realizados ensaios na direção paralela às fibras para seis espécies de madeira (Schizolobium amazonicum; Pinus elliottii; Pinus oocarpa; Hymenaea spp.; Lyptus ${ }^{\circledR}$ : híbrido Eucalyptus grandis e Eucalyptus urophylla, e Goupia glabra), utilizando quatro diâmetros $(8 \mathrm{~mm}, 10 \mathrm{~mm}, 12 \mathrm{~mm} \mathrm{e}$ $16 \mathrm{~mm}$ ) para os pinos metálicos. Os resultados experimentais obtidos de acordo com os procedimentos da norma EN 383:2007 apresentaram maior aderência com os valores especificados para o dimensionamento de ligações por pinos metálicos pela ABNT NBR 7190:1997, que são considerados iguais aos da resistência à compressão paralela às fibras. A adoção da força máxima de embutimento ou a força que causa o deslocamento relativo igual a $5 \mathrm{~mm}$ entre o pino metálico e o corpo de prova como critério para determinação da resistência da madeira ao embutimento pela EN 383:2007 se mostrou mais adequado que os critérios adotados pelas normas brasileira e americana.
\end{abstract}

Palavras-chave: Estruturas de madeira; Ligações; Parafusos. 


\section{INTRODUCTION}

In timber structures there should be connections between the various structural elements. Among the types of connections used, there are the metal-dowel type fasteners, glued connections, wood-dowel connections, metal ring connections, among others.

The metal-dowel type fasteners, which include common bolts, are the most widely used connectors because they can be used in various connection configurations, they are easy to use and of low cost (CALIL JUNIOR, et al., 2003). They are loaded perpendicular to its axis, causing bending of the metal pin and compressive stress in the wood (embedment stress).

The wood embedment strength results from a multiple stress state due to the contact pressure applied by the metal pin to the wall of the wood piece hole, tending to embed the pin on the wood (ALMEIDA, 1987, 1990).

The ABNTNBR 7190:1997 standard of the Brazilian Technical Standards Association (ABNT) defines the embedment strength of wood $\left(f_{e}\right)$ as the ratio between the applied force that causes residual strain of $2 \%$ $\left(\mathrm{F}_{\mathrm{e} 2 \%}\right)$ and the area resistant to embedding the metal pin (product between the diameter of the metal pin (d) and thickness (t) of the test piece).

The strain defined by the Brazilian standard is the ratio of the displacement of the metal pin considering a reference length of $14 \mathrm{~d}$. However, a similar procedure was not found in the other standards consulted. In countries that have a long standing tradition of building with wood, the resistance is determined from the slip (relative displacement) between the metal pin connector and the timber member. It is observed that the residual strain defined in ABNT NBR 7190:1997 can also be considered as a residual slip of $2.8 \%$ of the metal pin diameter.

The EN 383:2007 is the standard proposed by the EUROCODE 5:2004 -'Design of Timber Structures Part 1: General - Common rules and rules for building" - for determining the embedment strength of wood. According to this standard, the wood embedment strength $\left(f_{e}\right)$ is equal to the maximum load resisted by the test piece $\left(\mathrm{F}_{\text {máx }}\right)$ or the load that causes slip equal to $5 \mathrm{~mm}\left(\mathrm{~F}_{5 \mathrm{~mm}}\right)$, divided by the embedding area.

The North American Standard ASTM D5764:2007 determines the wood embedment strength from the quotient of the force that causes the residual slip of $5 \%$ of the metal pin diameter $\left(\mathrm{F}_{\mathrm{e} 5 \%}\right)$ and the embedding area.

There are significant differences in the ways to determine the embedment strength in the current Brazilian standards and the other standards. For example, FIGURE 1 shows the graphs for obtaining the embedment strength parallel to the grains $\left(\mathrm{f}_{\mathrm{e} 0}\right)$, according to the standards ABNT NBR 7190:1997, EN 383:2007 and ASTM D5764:2007.

Valle (1999), Stamato (2002), Almeida (2011) and Almeida (2014) used the guidelines of standards ABNT NBR 7190:1997 and EN 383: 2007 and found the highest mean values of embedment strength using the European method in relation to the Brazilian standard for different directions regarding the grains. This is because the Brazilian standard uses a graphic procedure with residual strain of $2 \%$ while the European standard determines a $5 \mathrm{~mm}$ slip limit if the failure of the test piece does not occur before.

In the absence of specific tests, the embedment strength of wood in a parallel to the grain direction can be determined using other parameters, such as: the compressive strength along the grains $\left(f_{c 0}\right)$, density $\left(\rho_{\text {ap }}\right)$, the characteristic density $\left(\rho_{\mathrm{k}}\right)$ and the diameter of the metal-dowel (d). The standards ABNT NBR 7190:1997, EUROCODE 5:2004 andNDS:2001 recommend

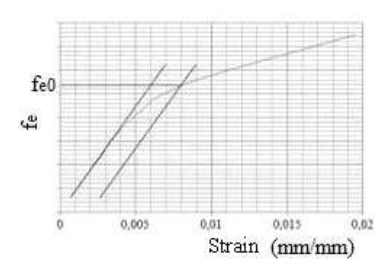

(a)

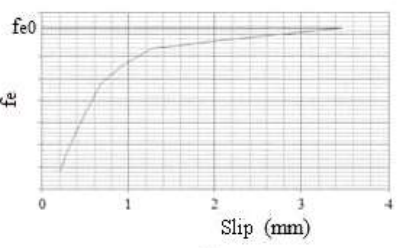

(b)

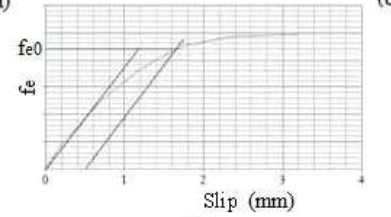

(c)

Figure 1 - Embedment strength of wood: (a) ABNT NBR 7190:1997, (b) EN 383:2007 e (c)ASTM D5764:2007.

Figura 1-Resistência da madeira ao embutimento: (a) ABNT NBR 7190:1997, (b) EN 383:2007 e (c) ASTM D5764:2007. 
Equations 1, 2 and 3, respectively, for calculating the embedment strength.

$$
\begin{aligned}
& \mathrm{f}_{\mathrm{e} 0}=\mathrm{f}_{\mathrm{c} 0} \\
& \mathrm{f}_{\mathrm{e} 0}=0,082(1-0,01 \cdot d) \cdot \rho_{\mathrm{k}} \\
& \mathrm{f}_{\mathrm{e} 0}=0,07725 \cdot \rho_{\mathrm{ap}}
\end{aligned}
$$

Oliveira (2001) tested various wood species with several metal pin diameters. He obtained higher average compressive strength values than the embedment strength value in all cases studied. He stated that because the ABNT NBR 7190:1997 has the same values as the two compressive strength values, it results in a lower connection capacity when using the experimentally obtained embedment strength value.

Stamato (2002), Almeida (2011), Nascimento et al. (2012), Almeida et al. (2013) and Almeida et al. (2014) working with woods of the genus Pinus, Eucalyptus, Schizolobium and Dipteryx also found higher compressive strength values when compared to the embedment strength.

Within this context, the purpose of this study is to compare test methods in order to provide support to establish a new test method for determining the embedment strength of wood.

\section{MATERIALS AND METHODS}

This study was carried out in the Laboratory for Woods and Wood Structures, Department of Structural Engineering, São Carlos School of Engineering, University of São Paulo (LaMEM-SET-EESC-USP).

\subsection{MATERIALS}

In this research six exotic and native wood species were used: Schizolobium amazonicum (Paricá); Pinus elliottii; Pinus oocarpa; Hymenaea spp. (Jatobá); Lyptus ${ }^{\circledR}$ (hybrid Eucalyptus grandis and Eucalyptus urophylla) and Goupia glabra (Cupiúba). The selection of these species was based on the range of compressive strength classes defined by ABNT NBR 7190:1997. For each species, homogeneous pieces were used to decrease the variability of wood properties. All test pieces were prepared using wood specimens with $12 \%$ moisture content.

Metal pins of $120 \mathrm{~mm}$ in length, and $8 \mathrm{~mm}, 10 \mathrm{~mm}$, $12 \mathrm{~mm}$ and $16 \mathrm{~mm}$ in diameter were used. Metal pins of $10 \mathrm{~mm}, 12 \mathrm{~mm}$ and $16 \mathrm{~mm}$ in diameter were used in this study as they are the most commonly used in the construction of wooden structures in the case of bolts; additionally, the $8 \mathrm{~mm}$ pin was used in order to verify the test procedures for a more flexible pin.

\subsection{METHODS}

\section{- Embedment Tests}

For the embedment tests in a parallel to the grain direction, the test pieces were prepared according to the standards ABNT NBR 7190:1997, EN 383: 2007 and ASTM D5764: 2007.

To study the test methods, tests were performed on three test pieces for each combination: wood standard - metal pin diameter. For the standards that specify performing more than one loading cycle (ABNT NBR 7190:1997 and EN 383:2007), an additional test piece was prepared for estimating the embedment strength. Altogether, 360 specimens were prepared, excluding those used for the preliminary embedment strength estimates.

The tests for determining the wood embedment strength were carried out in a computerized universal testing machine Dartec, $100 \mathrm{kN}$ capacity. The displacement between the metal pin and the test piece (slip) was measured using a LVDT (Linear Variable Diferential Transformer).

\section{- Mechanical Properties and Density of Wood}

The mechanical properties determined were the compressive strength parallel to the grains $\left(f_{c 0}\right)$, the modulus of elasticity in compression parallel to the grains $\left(\mathrm{E}_{\mathrm{c} 0}\right)$ and the shear strength parallel to the grains $\left(f_{v 0}\right)$.

The tests to determine the properties were carried out in accordance with the recommendations of Annex B of the ABNT NBR 7190:1997 "Determination of Wood Properties for Structural Design". For each species of wood and type of test, 12 tests were performed on defect free specimens randomly extracted from the wood pieces.

The density and compressive strength parallel to the grains were determined in the test pieces, measuring their mass and dimensions determine the volume.

\section{· Calculating Wood Embedment Strength}

Some standards allow obtaining the embedment strength in the parallel to the grain direction in relation

Revista Árvore, Viçosa-MG, v.40, n.4, p.741-748, 2016

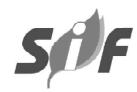


to other parameters. For the ABNT NBR 7190:1997, the parameter is the compressive strength parallel to the grains; as for NDS:2011 it is the density of wood. For EUROCODE 5:2004, the parameters are the metal pin diameter and the characteristic density of wood.

To calculate the embedment strength in a parallel to the grain direction according to the ABNT NBR 7190:1997, the average compressive strength values parallel to the grains were used.

The equations for calculating the embedment strength in the parallel and normal directions in relation to the grains according to EUROCODE 5:2004 use the characteristic density of wood. However, in this study the mean density values were used based on the comparison with the test results. To calculate the NDS:2011 standard, the mean density values of the woods were also used.

The equations used the nominal values of the metal pin diameters.

\section{RESULTS}

Tables 1 and 2 show, respectively, the embedment strength values in the parallel to the grain direction determined experimentally and those calculated using other parameters.

Table 1 - Embedment strength parallel to the grain $\left(\mathrm{f}_{\mathrm{e} 0}\right)$, in MPa.

Tabela 1 - Resistência ao embutimento na direção paralela às fibras $\left(f_{e \theta}\right)$, em MPa.

\begin{tabular}{|c|c|c|c|c|c|c|c|}
\hline Codes & $\mathrm{d}(\mathrm{mm})$ & $\begin{array}{r}\text { Schizolobium } \\
\text { amazonicum }\end{array}$ & $\begin{array}{c}\text { Pinus } \\
\text { elliottii }\end{array}$ & $\begin{array}{c}\text { Pinus } \\
\text { oocarpa }\end{array}$ & $\begin{array}{c}\text { Hymenaea } \\
\text { spp }\end{array}$ & Lyptus $\AA$ & $\begin{array}{l}\text { Goupia } \\
\text { glabra }\end{array}$ \\
\hline \multirow{4}{*}{$\begin{array}{l}\text { ABNT NBR } \\
7190: 1997\end{array}$} & 8 & 10.0 & 22.1 & 16.5 & 71.9 & 32.4 & 24.4 \\
\hline & 10 & 14.4 & 21.4 & 13.2 & 54.3 & 39.9 & 33.9 \\
\hline & 12 & 17.8 & 33.1 & 27.1 & 53.3 & 44.3 & 35.9 \\
\hline & 16 & 14.7 & 30.0 & 25.6 & 59.5 & 47.9 & 38.0 \\
\hline \multirow[t]{4}{*}{ EN 383:2007 } & 8 & 32.0 & 32.5 & 33.0 & 100.4 & 40.1 & 38.9 \\
\hline & 10 & 22.9 & 31.7 & 36.6 & 112,9 & 56.9 & 55.2 \\
\hline & 12 & 25.5 & 49.2 & 37.4 & 110.2 & 57.2 & 50.7 \\
\hline & 16 & 26.3 & 50.2 & 42.2 & 100.7 & 56.2 & 51.8 \\
\hline \multirow{4}{*}{$\begin{array}{c}\text { ASTM } \\
\text { D5764:2007 }\end{array}$} & 8 & 14.6 & 22.7 & 18.4 & 43.0 & 38.3 & 31.7 \\
\hline & 10 & 22.0 & 26.0 & 22.3 & 71.2 & 48.0 & 46.1 \\
\hline & 12 & 24.9 & 43.9 & 34.8 & 65.8 & 51.7 & 37.5 \\
\hline & 16 & 25.5 & 44.2 & 37.2 & 74.2 & 52.8 & 40.0 \\
\hline
\end{tabular}

Table 2 - Calculating wood embedment strength parallel to the grain (fe0), in MPa.

Tabela 2 - Resistência ao embutimento calculada na direção paralela às fibras (feO), em MPa.

\begin{tabular}{lccccccc}
\hline Standards & Species & $\begin{array}{c}\text { Schizolobium } \\
\text { amazonicum }\end{array}$ & $\begin{array}{c}\text { Pinus } \\
\text { elliottii }\end{array}$ & $\begin{array}{c}\text { Pinus } \\
\text { oocarpa }\end{array}$ & $\begin{array}{c}\text { Hymenaea } \\
\text { spp. }\end{array}$ & $\begin{array}{c}\text { Lyptus }{ }^{\circledR} \\
\text { A }\end{array}$ & $\begin{array}{c}\text { Goupia } \\
\text { glabra }\end{array}$ \\
\cline { 2 - 8 } & $\mathrm{f}_{\mathrm{c} 0}(\mathrm{MPa})$ & 22.9 & 33.6 & 38.4 & 89.6 & 53.6 & 44.5 \\
\cline { 2 - 8 } & $\rho\left(\mathrm{kg} / \mathrm{m}^{3}\right)$ & 320 & 480 & 540 & 970 & 550 & 890 \\
\hline ABNT NBR & $\mathrm{d}=8 \mathrm{~mm}$ & 22.9 & 33.6 & 38.4 & 89.6 & 53.6 & 44.6 \\
& & & & & & & \\
& $\mathrm{~d}=10 \mathrm{~mm}$ & 22.9 & 33.6 & 38.4 & 89.6 & 53.6 & 44.6 \\
& $\mathrm{~d}=12 \mathrm{~mm}$ & 22.9 & 33.6 & 38.4 & 89.6 & 53.6 & 44.6 \\
& $\mathrm{~d}=16 \mathrm{~mm}$ & 22.9 & 33.6 & 38.4 & 89.6 & 53.6 & 44.6 \\
\hline EN 383:2007 & $\mathrm{d}=8 \mathrm{~mm}$ & 24.1 & 36.2 & 40.7 & 73.2 & 41.5 & 67.1 \\
& $\mathrm{~d}=10 \mathrm{~mm}$ & 23.6 & 35.4 & 39.9 & 71.6 & 40.6 & 65.7 \\
& $\mathrm{~d}=12 \mathrm{~mm}$ & 23.1 & 34.6 & 39.0 & 70.0 & 39.7 & 64.2 \\
& $\mathrm{~d}=16 \mathrm{~mm}$ & 22.0 & 33.1 & 37.2 & 66.8 & 37.9 & 61.3 \\
\hline ASTM & $\mathrm{d}=8 \mathrm{~mm}$ & 24.7 & 37.1 & 41.7 & 74.9 & 42.5 & 68.8 \\
D5764:2007 & $\mathrm{d}=10 \mathrm{~mm}$ & 24.7 & 37.1 & 41.7 & 74.9 & 42.5 & 68.8 \\
& $\mathrm{~d}=12 \mathrm{~mm}$ & 24.7 & 37.1 & 41.7 & 74.9 & 42.5 & 68.8 \\
& $\mathrm{~d}=16 \mathrm{~mm}$ & 24.7 & 37.1 & 41.7 & 74.9 & 42.5 & 68.8 \\
\hline
\end{tabular}


Figure 2 show graphically the mean values of the experimentally obtained results in accordance with the standards ABNT NBR 7190:1997 (1), EN 383:2007 (2) and ASTM D5764:2004 (3) and the calculated results according to other parameters of the standardsABNTNBR7190:1997(4), EUROCODE 5:2004 (5) and NDS:2001 (6).

\section{DISCUSSIONS}

For all wood species and metal pin diameters used in this study, higher average $f_{e 0}$ values were found, determined by the EN 383:2007 method, compared to the Brazilian and American methods. This is because the European method uses the maximum load or the load that causes the $5 \mathrm{~mm}$ slip, while the other two methods use the load corresponding to the residual slip of 5\% (ASTM D5764:2007) and 2.8\% (ABNT NBR 7190:1997) of the pin diameter.

The testing method of the ABNT NBR 7190:1997 defines the reference length as 14 times the pin diameter to calculate the strain used to determine the wood

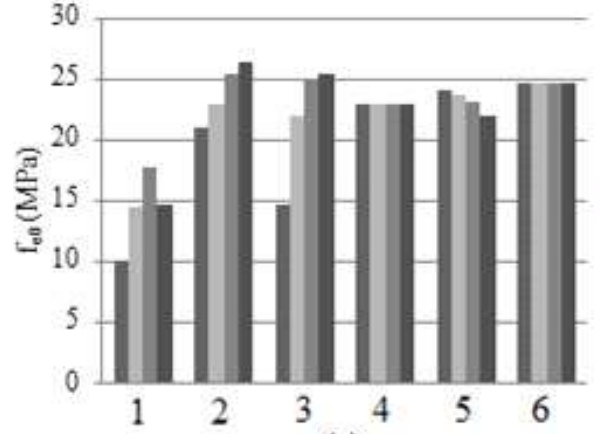

(a)

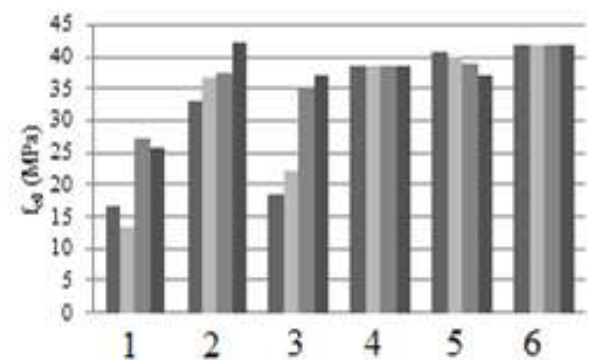

(c)





(b)

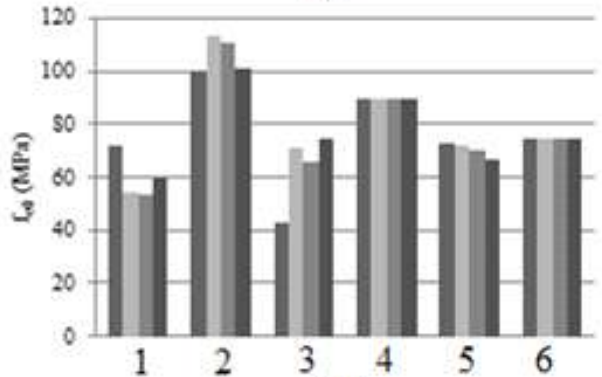

(d)

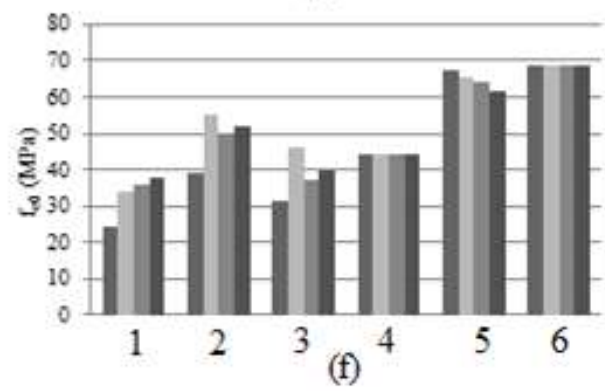

$=\mathrm{d}=8 \mathrm{~mm}=\mathrm{d}=10 \mathrm{~mm}=\mathrm{d}=12 \mathrm{~mm}=\mathrm{d}=16 \mathrm{~mm}$

Figure 2 - Experimental and calculated results of $\mathrm{f}_{\mathrm{e} 0}$ : (a) Schizolobium amazonicum Herb; (b); Pinus elliottii; (c) Pinus oocarpa, (d) Hymenaea spp; (e) Lyptus ${ }^{\circledR}$; (f) Goupia glabra.

Figura 2-Resultados experimentais e calculados de fo: (a) Schizolobium amazonicum Herb; (b); Pinus elliottii; (c) Pinus oocarpa, (d) Hymenaea spp; (e) Lyptus ${ }^{\circledR}$; (f) Goupia glabra. 
embedment strength. It is better to consider the slip between the metal pin and the wood piece according to the pin diameter or an absolute value, as recommended by the standards ASTM D5764:2007 and EN 383:2007, respectively, since it makes no sense defining the strain used by the ABNT NBR 7190:1997.

All test pieces tested in the parallel to the grains direction according to the EN 383:2007 reached the maximum load before reaching the $5 \mathrm{~mm}$ slip limit, but with large displacements. This means that a load distribution between all the pins that form a connection is possible.

The ASTM D5764:2007 method showed average $\mathrm{f}_{\mathrm{e} 0}$ values that were higher than those found by the ABNT NBR 7190:1997 for all the wood species and metal pins used (except for Hymenaea spp with a metal pin of $8 \mathrm{~mm}$ in diameter, probably due to the natural variability of the wood mechanical properties).

The experimental values achieved using $8 \mathrm{~mm}$ diameter metal pins were systematically much lower than the values determined using larger diameter metal pins. This may be due to the lower bending rigidity of the $8 \mathrm{~mm}$ metal pins, which causes greater stress concentrations. In this regard, the recommendation of the ABNT NBR 7190:1997 to use bolt diameters equal to or larger than $10 \mathrm{~mm}$ appears to be adequate.

The average $f_{e 0}$ value determined by the ABNT NBR 7190:1997 test method was lower than that calculated by the same standard (equal to the compressive strength parallel to the grains value) for all the cases evaluated. This shows that the experimental method used by the Brazilian standard tends to underestimate the embedment strength values in relation to the most widely used value, defined as being equal to the compressive strength parallel to the grain. It is observed that the use of the compressive strength parallel to the grain value did not result in recorded failures in designed connections.
The average $f_{e 0}$ values calculated by the ABNT NBR 7190:1997 were very close to those experimentally determined by the EN 383:2007 method. This is because both methods use a maximum load (compressive strength parallel to the grains and embedment, respectively) as parameter for determining $\mathrm{f}_{\mathrm{e} 0}$.

The EUROCODE 5:2007 and NDS:2001 use the wood density as parameters for calculating the embedment strength. However, for the hardwoods, woods with higher densities do not necessarily have higher strength values; therefore, in this case, the best strength estimate is given by the modulus of elasticity. This aspect is observed in the results achieved for the Lyptus ${ }^{\circledR}$ and Goupia glabra (Table 3). For hardwoods, the density should not be used to estimate the wood embedment strength. The Brazilian standard uses the embedment strength equal to the compressive strength for the direction parallel to the grains, which appeared to be adequate, considering the results achieved in the tests performed, in accordance with the EN 383:2007.

In most cases, the NDS:2001 method showed the highest values accompanied by the EUROCODE 5:2004 method, and finally the ABNT NBR 7190:1997 method. Interestingly, the Brazilian and American calculation methods show calculated $\mathrm{f}_{\mathrm{e} 0}$ values that are the same for any metal pin diameter, however, the EUROCODE 5:2004 method showed a lower $\mathrm{f}_{\mathrm{e} 0}$ value with the increase in the metal pin diameter value used.

\section{CONCLUSIONS}

For all wood species and metal pin diameters evaluated, there were higher average values of wood embedment strength determined by the EN 383:2007 method, followed by those obtained by the ASTM D5764:2007 and ABNT NBR 7190:1997 methods. This is because the Brazilian and American standards use a graphical method which results in smaller embedment strength values when compared with the EN 383:2007 method.

Table 3 - Mechanical properties and density.

Tabela 3 - Propriedades mecânicas e densidade aparente.

\begin{tabular}{|c|c|c|c|c|}
\hline Species & $\mathrm{f}_{\mathrm{c} 0}(\mathrm{MPa})$ & $\mathrm{E}_{\mathrm{c} 0}(\mathrm{MPa})$ & $\mathrm{f}_{\mathrm{v} 0}(\mathrm{MPa})$ & $\rho_{\mathrm{ap}}\left(\mathrm{kg} / \mathrm{m}^{3}\right)$ \\
\hline Schizolobium amazonicum & 22.9 & 8210 & 9.9 & 320 \\
\hline Pinus elliottii var.elliottii & 33.6 & 9312 & 18.0 & 480 \\
\hline Pinus oocarpa & 38.4 & 12972 & 11.0 & 540 \\
\hline Hymenaea spp & 89.6 & 23775 & 19.4 & 970 \\
\hline Lyptus ${ }^{\circledR}$ & 53.6 & 22559 & 12.0 & 550 \\
\hline Goupia glabra & 445 & 11114 & 14.5 & 890 \\
\hline
\end{tabular}

Revista Árvore, Viçosa-MG, v.40, n.4, p.741-748, 2016 
The results obtained with $8 \mathrm{~mm}$ metal pins were not satisfactory, hence it is interesting to point out the relevance of the recommendation of the ABNT NBR 7190:1997 of using bolts with diameters that are greater than or equal to $10 \mathrm{~mm}$.

In none of the tests performed according to the EN 383:2007 was the slip limit of $5 \mathrm{~mm}$ reached.

Using the maximum load or the load that causes the slip of $5 \mathrm{~mm}$ as a criterion to determine the embedment strength of wood by the EN 383:2007 is more appropriate than the criteria adopted by the Brazilian and American standards, as it provides values which are consistent with the embedment strength values calculated from the compressive strength parallel to the grains, as currently indicated by the ABNT NBR 7190:1997.

Therefore, we propose using the test method of the EN 383:2007 for determining the wood embedment strength to replace the current test method of the ABNT NBR 7190:1997.

\section{ACKNOWLEDGMENTS}

The authors thank CNPq and CAPES for financial support and grants.

\section{REFERENCES}

ALMEIDA, D.H. Proposta de método de ensaio para determinação da resistência da madeira ao embutimento. 2014. 130f. Dissertação (Mestrado em Engenharia de Estruturas) - Escola de Engenharia de São Carlos, Universidade de São Paulo, São Carlos, 2014.

ALMEIDA, D.H.; SCALIANTE, R.M.; CHRISTOFORO, A.L.; LAHR, F.A.R; MOLINA, J.C.; CALIL JUNIOR, C. Comparação das resistências ao embutimento paralelo às fibras de madeiras de pinus oocarpa, cumaru e pinus taeda. Ambiente Construído, v.14, n.3, p.113-119, 2014.

ALMEIDA, D.H.; CAVALHEIRO, R.S; SCALIANTE, R.M.; CHRISTOFORO, A.L.; CALIL JUNIOR, C; LAHR, F.A.R. Full characterization of strength properties of Schizolobiumamazonicum Wood for timber structures. International Journal of Engineering \& Technology, v.13, n.6, p.93-96, 2013.

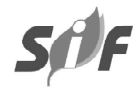

ALMEIDA, D.H. Análise das resistências de embutimento e de compressão para madeiras de Pinus e Eucalipto. 2011. 100f. Monografia (Graduação em Engenharia Industrial Madeireira) - Campus Experimental de Itapeva, Universidade Estadual Paulista, Itapeva, 2011.

ALMEIDA, P.A.O. Estruturas de grande porte de madeira composta. 1990. $280 \mathrm{f}$. Tese (Doutorado em Engenharia de Estruturas) Escola Politécnica, Universidade de São Paulo, São Paulo, 1990.

ALMEIDA, P.A.O. Uniões pregadas de madeira. 1987. 174f. Dissertação (Mestrado em Engenharia de Estruturas) - Escola Politécnica, Universidade de São Paulo, São Paulo, 1987.

\section{AMERICAN NATIONAL STANDARD FOR} WOOD PRODUCTS/AMERICAN FOREST AND PAPER ASSOCIATION. NDS: American national design and specification for wood construction. Washington: ANSI/AF\&PA, 2001.

\section{AMERICAN SOCIETY FOR TESTING AND} MATERIALS - ASTM D5764: Evaluating dowelbearing strength of wood and wood-based products. West Conshohocken: 2007.

ASSOCIAÇÃO BRASILEIRA DE NORMAS TÉCNICAS - ABNT. NBR 7190: Projeto de estruturas de madeira. Rio de Janeiro: 1997.

CALIL JUNIOR, C.; LAHR, F.A.R.; DIAS, A.A. Dimensionamento de elementos estruturais de madeira. Barueri: Manole, 2003.

EUROPEAN COMMITEE FOR STANDARDZATION. EN 383: Timber structures. Test methods. Determination of embedding strength and foundation values for dowel type fasteners. Brussels: 2007.

\section{EUROPEAN COMMITEE FOR} STANDARDIZATION. EUROCODE 5: Design of timber structures - Parte 1 - 1: general rules and rules for buildings. Brussels: CEN, 2004.

NASCIMENTO, A.M.; XAVIER, C.N.; SILVA, M.A.; NASCIMENTO, L.A.C. Resistências à compressão e ao embutimento e densidade das

Revista Árvore, Viçosa-MG, v.40, n.4, p.741-748, 2016 
madeiras de Corymbiacitriodora,

Eucalyptuspellita e Eucalyptuspaniculata. In: ENCONTRO BRASILEIRO EM MADEIRAS E EM ESTRUTURAS DE MADEIRA - EBRAMEM, 13., 2012, Vitória, Espírito Santo. Anais... Vitória: UFES, 2012. CD-ROM.

OLIVEIRA, M.A.M. Ligações com pinos metálicos em estruturas de madeira. 2001. 137f. Dissertação (Mestrado em Engenharia de Estruturas) - Escola de Engenharia de São Carlos, Universidade de São Paulo, São Carlos, 2001.
STAMATO, G.C. Ligações em estruturas de madeira compostas por chapas de madeira compensada. 2002. 158f. Tese (Doutorado em Engenharia de Estruturas) - Escola de Engenharia de São Carlos, Universidade de São Paulo, São Carlos, 2002.

VALLE, A. Rigidez de ligações com parafusos em estruturas de madeira laminada colada. 1999. 193f. Tese (Doutorado em Engenharia Civil) - Escola Politécnica, Universidade de São Paulo, São Paulo, 1999. 